\title{
A Novel Engineering Education Innovation Pattern with Design Ideas and Robot Maker Practice
}

\author{
Aibin Zhu ${ }^{1,2}$, Huang Shen ${ }^{1,2}$, Zhitao Shen ${ }^{1,2}$, Yao Tu ${ }^{1,3}$, and Jiyuan Song ${ }^{1,2}$ \\ ${ }^{1}$ Shaanxi Key Laboratory of Intelligent Robots, 710049 Xi'an, China \\ ${ }^{2}$ Institute of Robotics \& Intelligent Systems, Xi'an Jiaotong University, 710049 Xi'an, China \\ ${ }^{3}$ Key Laboratory of Education Ministry for Modern Design and Rotor-Bearing System, 710049 Xi'an, China
}

\begin{abstract}
Traditional engineering education of innovative thinking mainly focused on knowledge imparting, thinking and learning, but it weakens the cultivation of students' practical ability. In this paper, a new pattern of innovative thinking engineering education is proposed, which combines abstract design innovation with specific robot maker practice. By offering general course for all professional students, it teaches the theory, methods and tools of systematic innovative thinking, and cultivates students' system design methods and innovative thinking. Taking the design and production process of robots as the object and content of practical teaching, the traditional teaching pattern centered on teachers, classrooms and textbooks is changed, teachers' reflection on teaching is promoted, so that it can be truly changed from a lecturer to an inspirator of learning, at the same time, teaching flexibility is increased, and students' highlevel thinking and practical abilities are improved. Classroom statistics show that $92.14 \%$ of the students think that their innovative thinking ability has been improved, and $90.71 \%$ of the students consider that their practical ability has been enhanced. It shows that the engineering education innovation pattern with design ideas and robot maker practice can inspire students' innovative thinking, while improving students' robotic practical ability.
\end{abstract}

\section{Introduction}

Cultivating innovative talents is the urgent need of the times and the responsibility of universities[1].Traditional teacher-centered teaching mode in educational activities has a set of fixed curriculum model, which leads to the passive learning situation of students, hinders the development of students' innovative thinking, is not conducive to the cultivation of innovative talents, and thus affects the quality of personnel training. In the past, innovative thinking engineering education mainly focused on knowledge imparting, focusing on students' learning of textbook knowledge in the classroom, but the cultivation of students' practical ability is weak. Practical ability is the ability to solve practical problems that people cultivate and develop in practical activities. Innovation is the creative activity that people change objective reality[2].

Institutions of higher learning have generally recognized the importance of practical ability to the cultivation of high-quality talents[3].At present, many colleges and universities are making great efforts to build engineering education bases. However, influenced by the traditional exam-oriented education, students' learning is still mainly passive acceptance and giving priority to exams. Many students are indifferent to selfstudy, creative practice and innovation in the process of Engineering teaching. After systematic professional course learning, they still can not have strong professional ability and innovative spirit of hard exploration [4].Innovative design is a creative invention that transforms information knowledge and technology into integrated innovation and overall solution and realizes application value. It is the forerunner and key link of manufacturing service innovation [5].Cultivating innovative talents has become the common value pursuit of higher education all over the world. Cultivating innovative talents is not only a theoretical issue, but also an important practical issue [6].

The current robotics technology is a strategic high technology which integrates many disciplines, such as machinery, electronics, control, biology, medicine, materials and so on[7]. It plays an important supporting and leading role in the development of related technology and industry. Robot has formed a multidisciplinary and multi-domain knowledge system, and the traditional curriculum education experiment or practice curriculum design method has been unable to meet the requirements of the cross-disciplinary robot.

This paper puts forward a new pattern of innovative thinking engineering education, which combines abstract design innovation with specific robot maker practice. It aims to cultivate students' systematic innovative ideas and guide them to analyze and solve practical problems by using the holistic method system of innovative theory

\footnotetext{
* Corresponding author: abzhu@mail.xjtu.edu.cn

Research supported by research project of undergraduate teaching reform in Xi'an Jiaotong University(No.1614Y)
} 
and innovative tools, so as to improve students' innovative thinking ability and robots practical ability.

\section{A new pattern of innovative thinking engineer- ing education}

At present, engineering education is mainly to train engineers engaged in general design and manufacturing, which needs to be gradually transformed into innovative entrepreneurship education oriented by technological innovation, with the long-term goal of cultivating leading talents in manufacturing industry; from classroom education as the main place in traditional engineering education, it gradually transforms into innovative education pattern of engineering system oriented to systematic innovation thinking.

This paper puts forward a new pattern of Engineering Education of innovative thinking, which combines abstract with specific. As shown in Fig. 1, it mainly combines the theory and method of abstract system design innovation with specific practice of robot innovation to train students' innovation ability and robot practice ability.

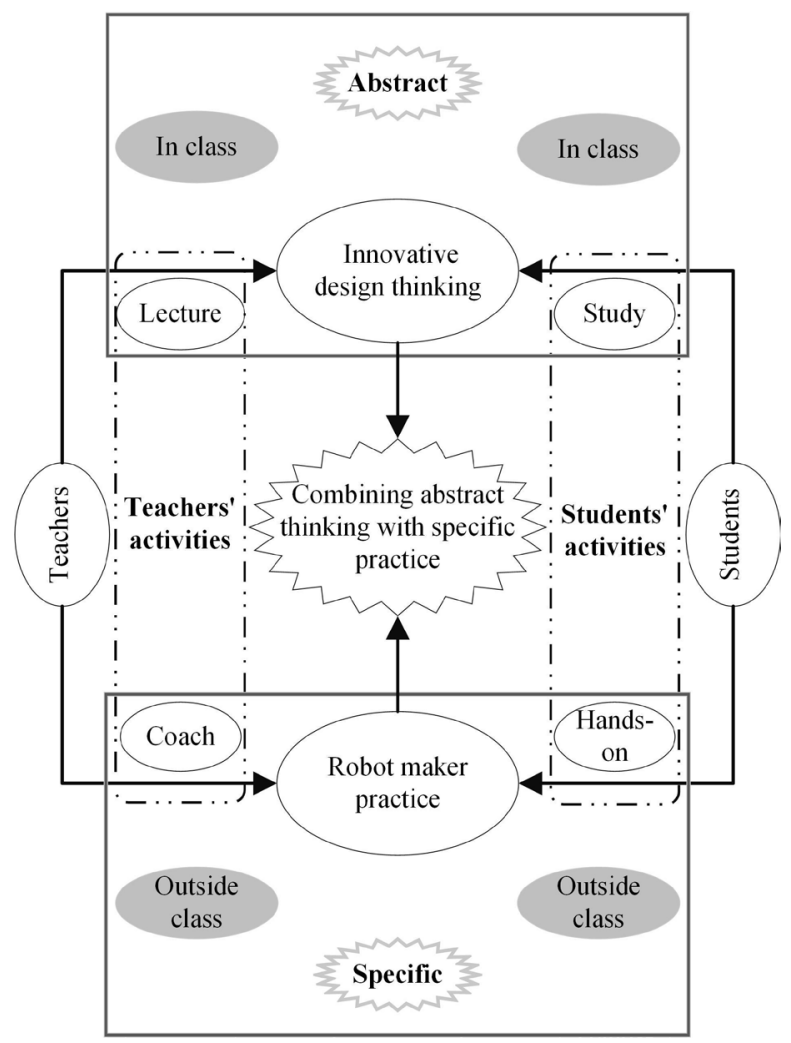

Fig. 1. A new pattern of combining abstract innovative design with specific robot maker practice.

From Fig. 1, we can see that the main body of the new pattern of innovative thinking engineering education is composed of students and teachers, the teaching environment is in and out of class, and the teaching content is abstract theory and specific practice. Teachers' main activities are to teach the theory and method of abstract system innovation design in class, to instruct students to carry out specific practice activities of robot maker practice after class; students' main activities are to learn innovation theory in class, carry out robot hands-on practice after class, and put forward the problems encountered, and communicate with teachers.

\section{Method}

According to the above-mentioned new pattern of innovative thinking engineering education, a general course of innovative thinking and robot maker practice for different disciplines and specialties is offered, which teaches the theory, methods and tools of systematized innovative thinking, cultivates students' system design methods and innovative thinking, and takes the process of robot design and production as the object and content of practical teaching to improve students' robots practical ability.

\subsection{Basic information of students}

A total of 140 students participated in the course, 124 boys and 16 girls. The grade distribution of all the students is shown in Table 1 . The number of freshmen is the largest, totaling 121 , accounting for $86.43 \%$.

Table 1. Grade distribution

\begin{tabular}{|c|c|c|}
\hline Grade & $\begin{array}{c}\text { The number } \\
\text { of students }\end{array}$ & Proportion \\
\hline Freshman & 121 & $86.43 \%$ \\
\hline Sophomore & 8 & $5.71 \%$ \\
\hline Junior & 9 & $6.43 \%$ \\
\hline Senior & 2 & $1.43 \%$ \\
\hline
\end{tabular}

Students' majors cover science, engineering. The distribution of specific professional categories is shown in Table 2. As we can see from the table, students mainly come from science and engineering students, of which engineering students are the most, accounting for $80.00 \%$.

Table 2. Major distribution

\begin{tabular}{|c|c|c|}
\hline Major & $\begin{array}{c}\text { The number } \\
\text { of students }\end{array}$ & Proportion \\
\hline Science & 28 & $20.00 \%$ \\
\hline Engineering & 112 & $80.00 \%$ \\
\hline
\end{tabular}

All the students are divided into 12 groups, each of which contains students of different grades and majors, so that they can cooperate with each other later. The situation of each group is shown in Table 3. 
Table 3. Grouping result

\begin{tabular}{|c|c|c|}
\hline $\begin{array}{c}\text { Group } \\
\text { number }\end{array}$ & $\begin{array}{l}\text { The number } \\
\text { of students }\end{array}$ & Proportion \\
\hline 1 & 9 & $6.43 \%$ \\
\hline 2 & 10 & $7.14 \%$ \\
\hline 3 & 10 & $7.14 \%$ \\
\hline 4 & 12 & $8.57 \%$ \\
\hline 5 & 13 & $9.29 \%$ \\
\hline 6 & 10 & $7.14 \%$ \\
\hline 7 & 9 & $6.43 \%$ \\
\hline 8 & 11 & $7.86 \%$ \\
\hline 9 & 11 & $7.86 \%$ \\
\hline 10 & 11 & $7.86 \%$ \\
\hline 11 & 14 & $10.00 \%$ \\
\hline 12 & 10 & $7.14 \%$ \\
\hline
\end{tabular}

\subsection{Stimulating students' innovative thinking}

Teachers teach students the theory, methods and tools of systematic innovative thinking, train students' system design methods and innovative thinking, and provide students with the theoretical basis of innovative design. Students apply the system method of engineering innovation, disruptive innovation method[8], SCAMPER innovation method[9] and engineering TRIZ innovation method[10] they have learnt to carry out requirement analysis, functional decomposition, conceptual design, and structural design and analysis for the practical objects of robots.

As shown in Fig. 2, on the one hand, teachers teach related innovative methods, on the other hand, they guide students to analyze the object of robot practice. On the one hand, students need to learn innovative thinking methods, on the other hand, they need to analyze the object of robot practice, and give timely feedback to teachers and get answers to the problems.

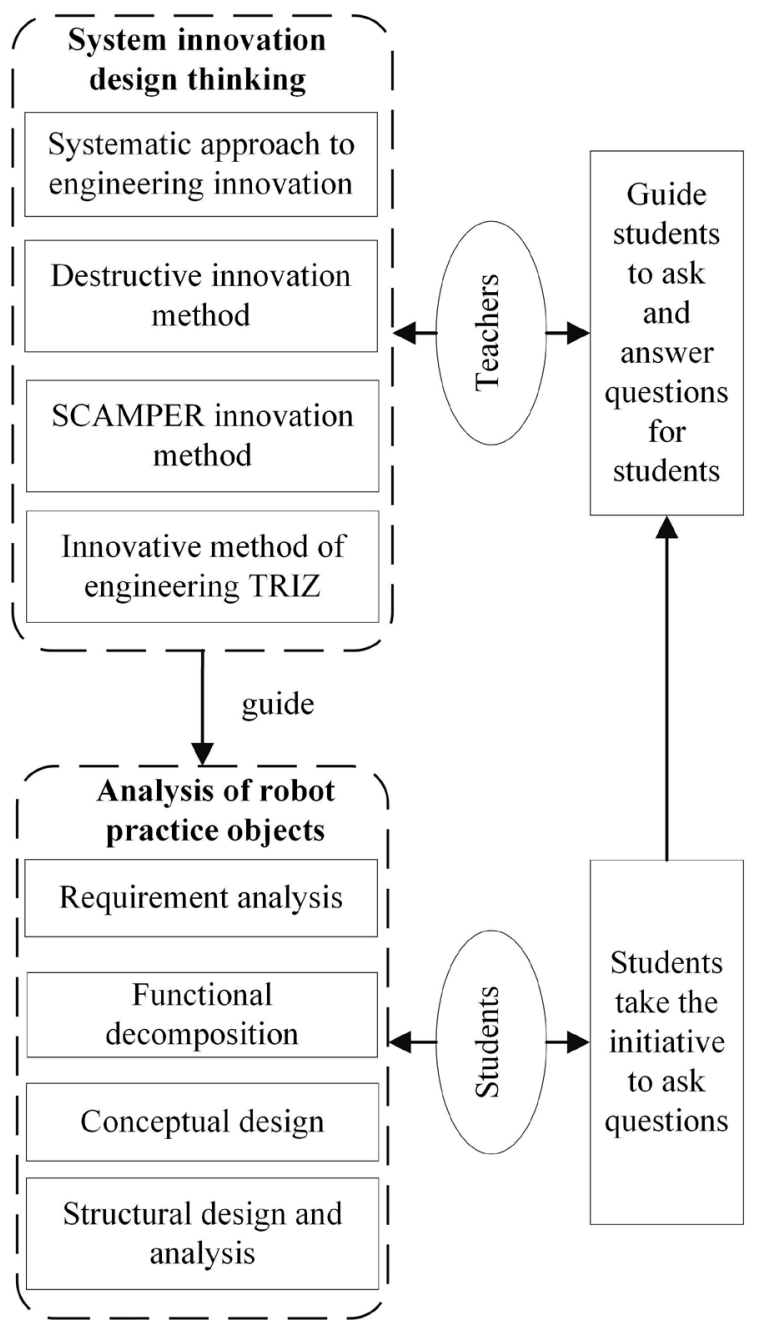

Fig. 2. Stimulating students' innovative thinking.

\subsection{Students' hands-on practice}

Considering the time, difficulty, cost and students' acceptance, teachers designed a systematic object-driven practical scheme. Practice content includes the practice of robot maker system based on arduino controller and 3D printing software/hardware and practice, as well as the curriculum practice for four types of practice objects.

As shown in Fig. 3, the first of four kinds of practical objects is the upper extremity exoskeleton, the second is the lower extremity exoskeleton, the third is the bionic spherical robot, and the fourth is the wall/cable/pole climbing robot. Among them, robot maker practice 1,2 is suitable for all professional students, and 3,4 is suitable for engineering students. Teachers provide targeted practical guidance.

Students are encouraged to learn how to select materials, use tools, 3D printing and assembly to produce robot prototypes, and how to use control platform to achieve mechanical and electrical control, so that the prototype can complete the established functions and actions. 


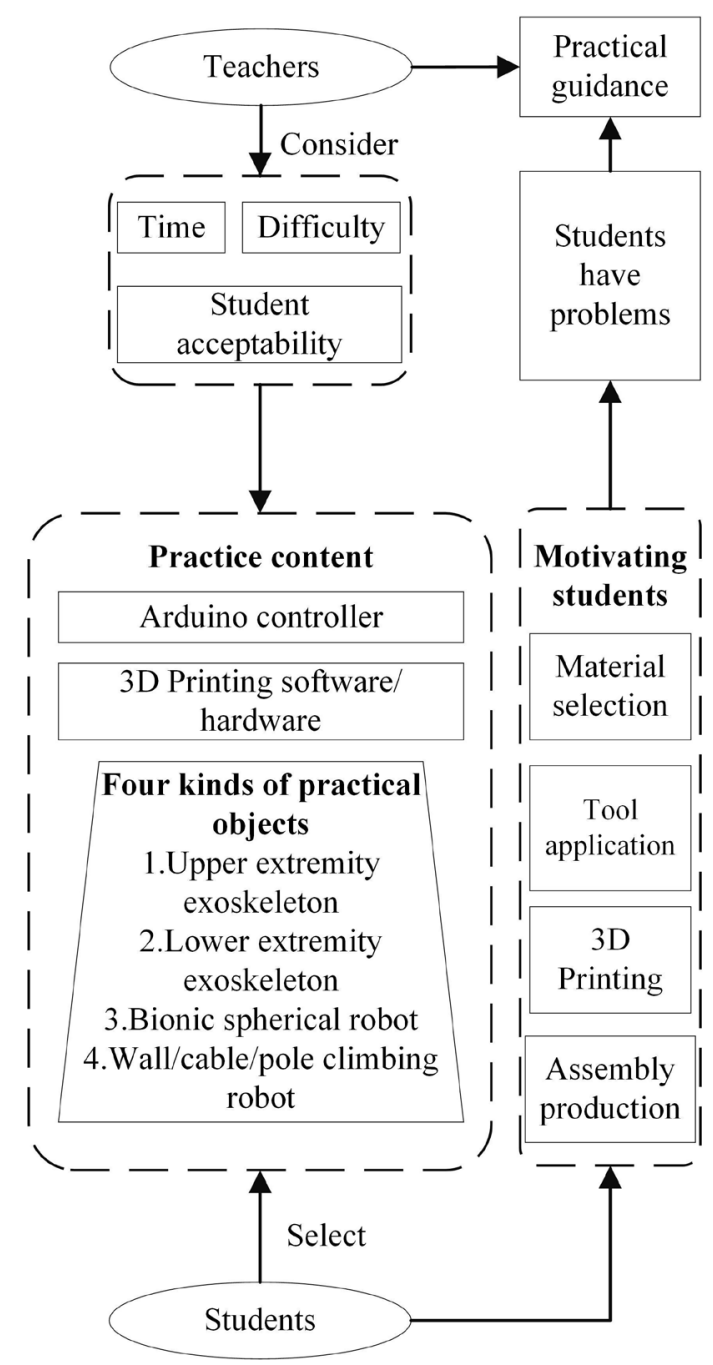

Fig. 3. Students' hands-on practice.

\subsection{Entrepreneurship expansion}

In order to expand the content of the course and let students get in touch with the current upsurge of innovation and entrepreneurship activities, the course specially sets up the teaching contents of "inviting" and "getting out", so as to realize the development of entrepreneurship.

"Inviting" includes inviting maker space, corporate mentors to share their experience and lessons in innovative thinking and robotic practice, and introducing robotic innovation and entrepreneurship in the case of high-tech companies in the robotic industry, such as Silicon Valley. Teachers encourage students to apply what they have learnt, apply the evaluation methods of engineering innovation schemes, engineering innovation enabling technologies, and discuss with business mentors how to write and evaluate business plans for high-tech entrepreneurship.

"Getting out" includes organizing students to discuss and exchange robotic innovation and entrepreneurship in well-known maker space, encouraging them to participate in outstanding project roadshow of robot maker, project roadshow and entrepreneurship development in activities such as International Creator
Festival, National Double Creation Week and Silk Road Robot Creative Competition.

\section{Result and analysis}

The new pattern of innovative thinking engineering education, which combines the classroom education of systematic innovative thinking with the cross-innovative practical education of robot maker, is characterized by cultivating students' systematic innovative ideas and guiding them to analyze and solve practical problems by using the overall method system of innovative theory and tools.

\subsection{Course scene display}

As shown in Fig. 4, (a) shows the class situation and students' communication, (b) displays students' threedimensional model and iterated objects, (c) shows other robot objects made by students.
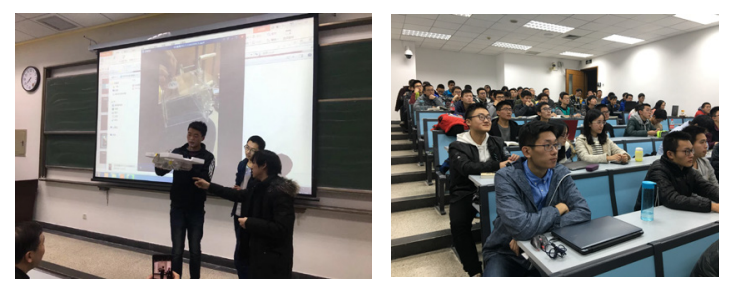

(a)
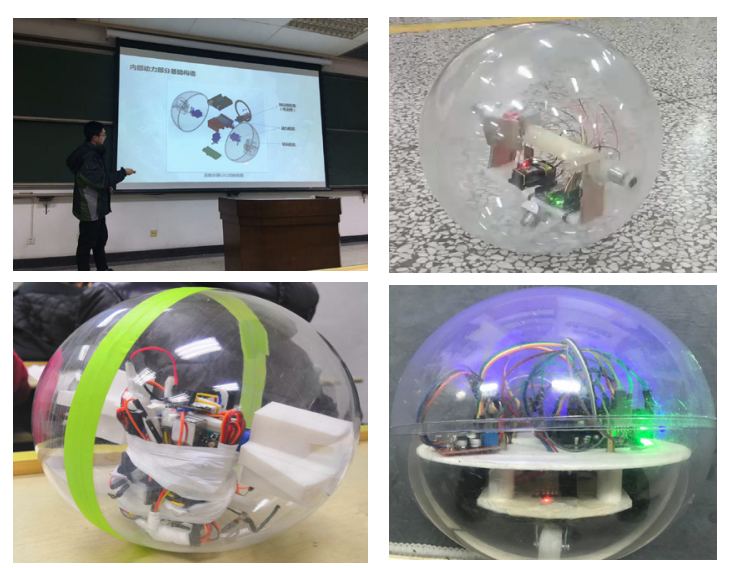

(b)

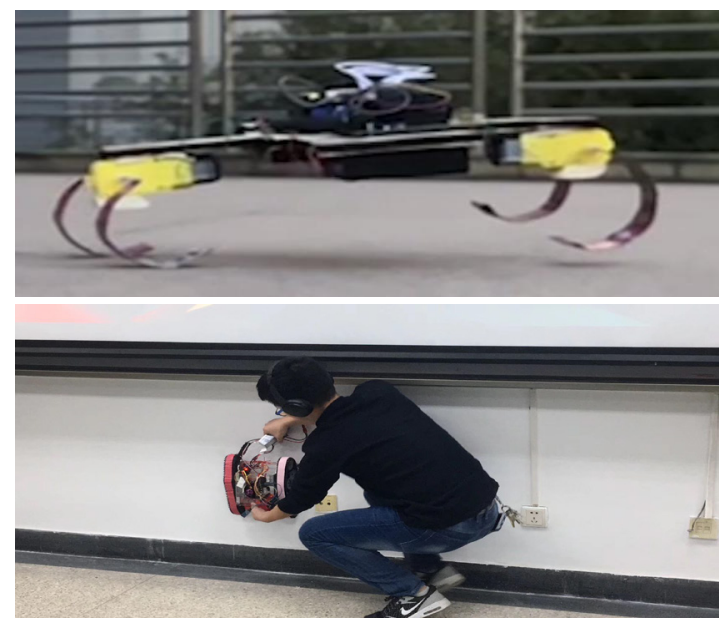




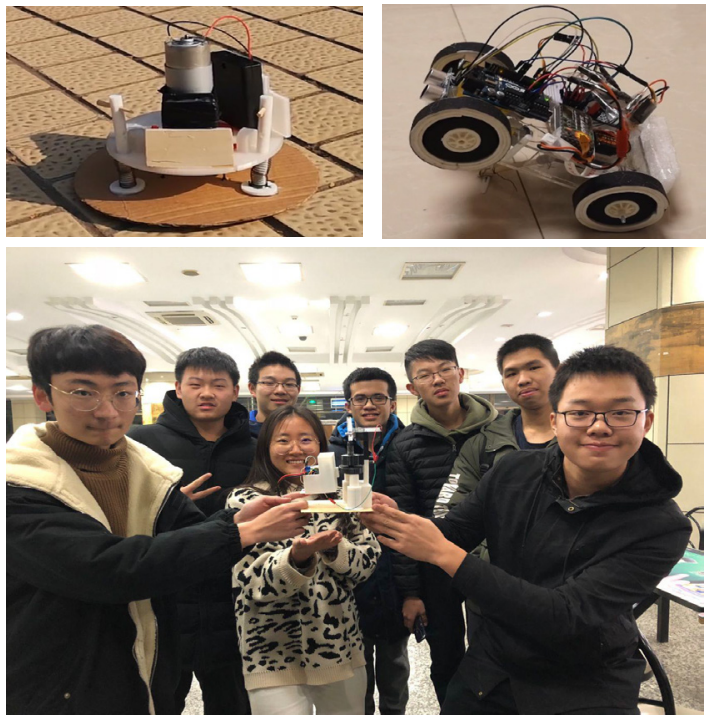

(c)

Fig. 4. Course scene display.

\subsection{Course investigation and analysis}

The purpose of the new pattern of innovative thinking engineering education is to improve students' innovative thinking ability and robotic practical ability. In order to evaluate the effect of the new pattern of engineering education, an anonymous questionnaire survey was conducted among 140 students who participated in the course.

\subsubsection{Students' evaluation of the course}

Students scored the prospectiveness of the course content and the enlightenment of teachers' classroom cases. Setting a full score of 10 points, the higher the score, the more advanced the use of course and the more enlightening the classroom cases.

The result of a questionnaire on prospectiveness of course content is shown in Fig. 5, the proportion of people with more than 6 points in the total number is $96.43 \%$, and the overall average score is 8.91 , which shows that students think the content of this course has good prospectiveness.
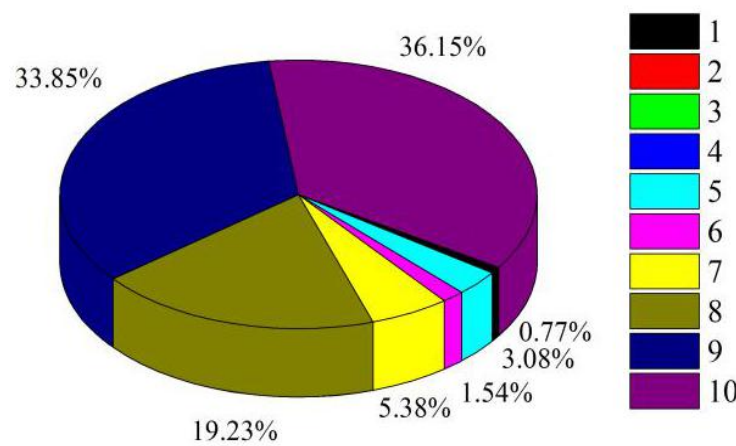

$19.23 \%$

Fig. 5. Prospectiveness of course content.
The result of a questionnaire on enlightenment of teachers' classroom cases is shown in Fig. 6, the proportion of people with more than 6 points in the total number is $99.29 \%$, and the overall average score is 8.82 , which indicates that students think that teacher's classroom case is very enlightening.

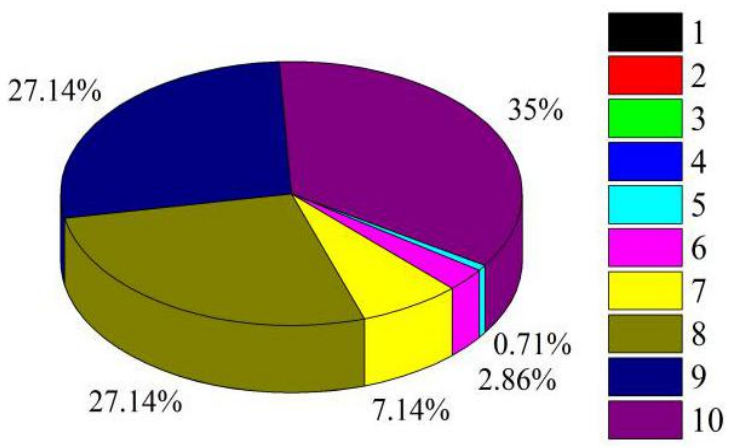

Fig. 6. The enlightenment of teachers' classroom cases.

\subsubsection{Self-assessment of students' ability}

Students make multiple choices on innovative methods taught by teachers in class. The results show that most of the students are most impressed by destructive innovation, accounting for $88.57 \%$.

Table 4. Survey of innovative methods

\begin{tabular}{|c|c|c|}
\hline $\begin{array}{c}\text { Innovative } \\
\text { methods }\end{array}$ & $\begin{array}{c}\text { The } \\
\text { number of } \\
\text { students }\end{array}$ & Proportion \\
\hline $\begin{array}{c}\text { Destructive } \\
\text { innovation } \\
\text { methods }\end{array}$ & 124 & $88.57 \%$ \\
\hline $\begin{array}{c}\text { SCAMPER } \\
\text { innovation } \\
\text { method }\end{array}$ & 62 & $44.29 \%$ \\
\hline $\begin{array}{c}\text { Engineering } \\
\text { TRIZ innovation } \\
\text { method }\end{array}$ & 43 & $30.71 \%$ \\
\hline Other & 5 & $3.57 \%$ \\
\hline
\end{tabular}

Students make multiple choices about the skills they have improved in the process of robot practice.The results show that $47.14 \%$ of the students think that their ability of CAD design has been improved, followed by $29.29 \%$ of the students think that their ability of arduino control and $3 \mathrm{D}$ printing has been improved. 
Table 5. Survey of practical skills

\begin{tabular}{|c|c|c|}
\hline Practical skills & $\begin{array}{c}\text { The } \\
\text { number of } \\
\text { students }\end{array}$ & Proportion \\
\hline $\begin{array}{c}\text { CAD three- } \\
\text { dimensional } \\
\text { model }\end{array}$ & 66 & $47.14 \%$ \\
\hline $\begin{array}{c}\text { Arduino } \\
\text { controller }\end{array}$ & 41 & $29.29 \%$ \\
\hline 3D Printing & 41 & $29.29 \%$ \\
\hline Other & 18 & $12.86 \%$ \\
\hline
\end{tabular}

Finally, the students make a number of choices about the innovative thinking ability, practical ability and collaborative communication ability of the whole course. The results are shown in Table $6,92.14 \%$ of the students believe that their innovative thinking ability has been improved, and $90.71 \%$ of the students think that their practical ability has been improved, indicating that the new pattern of innovative thinking engineering education can stimulate students' innovative thinking and improve students' robotic practical ability.

Table 6. A survey of students' comprehensive ability

\begin{tabular}{|c|c|c|}
\hline $\begin{array}{c}\text { Comprehensive } \\
\text { ability }\end{array}$ & $\begin{array}{c}\text { The } \\
\text { number of } \\
\text { students }\end{array}$ & Proportion \\
\hline $\begin{array}{c}\text { Innovative } \\
\text { thinking ability }\end{array}$ & 129 & $92.14 \%$ \\
\hline Practical ability & 127 & $90.71 \%$ \\
\hline $\begin{array}{c}\text { Collaborative } \\
\text { communication } \\
\text { ability }\end{array}$ & 118 & $84.29 \%$ \\
\hline Other & 25 & $17.86 \%$ \\
\hline
\end{tabular}

\section{Conclusion}

In view of the problem that the former engineering education of innovative thinking mainly focuses on knowledge imparting and the cultivation of students' practical ability is weak, this paper puts forward a new pattern of innovative thinking engineering education, which combines abstract design innovation with specific robot maker practice. By offering general courses for all professional students, we can teach students the theory, methods and tools of systematic and innovative thinking, cultivate students' system design methods and innovative thinking, and take the process of robot design and production as the object and content of practical teaching.

The results of the questionnaire survey show that $92.14 \%$ of the students think that their innovative thinking ability has been improved, and $90.71 \%$ of the students believe that their practical ability has been enhanced. It shows that the new pattern of innovative thinking engineering education can stimulate students' innovative thinking, and improve students' robotic practical ability.

\section{Acknowledgment}

The authors greatly appreciate the financial support from Research Project of Undergraduate Teaching Reform in Xi'an Jiaotong University(No.1614Y).

\section{References}

1. Wenjin Ke, Research of the personnel training model under modern university system, Beijing Education(Higher Education) 7, 13-17, (2007)

2. Chunlong Zheng, Hongyan Shao, Construction and Implementation of Practical Teaching System in Colleges and Universities Aiming at Cultivating Innovative Practical Ability, China Higher Education Research 4, 85-86, (2007)

3. Haocheng Wang, On the Necessity of Creativity Thinking Method Integration in Higher Engineering Education, Journal of Anhui University of Technology(Social Sciences Edition) 27, 5, 97-98, (2010)

4. Zhonghai Li, Hai Jin, Jianguo Cui, Xiaohong Xing, Yang Cao, Research on the Self-regulated Learning Model of Engineering Students Embodying the Awareness of Independent Innovation-Taking the Teaching Practice of Digital Signal Processing as an Example, Journal of Innovation and Enterprise Education 7, 2, 80-82, (2016)

5. Yongxiang Lu, Evolution and Value of Design, Engineering Science 19, 3, 1-5, (2017)

6. Hong Zhu, Exploration and Practice of Innovative Talents Training Model in Colleges and Universities, The Road to Success 19, 1-3, (2015)

7. Garduño-Aparicio M, Rodríguez-Reséndiz J, Macias-Bobadilla G, Thenozhi S, A Multidisciplinary Industrial Robot Approach for Teaching Mechatronics-Related Courses, IEEE Transactions on Education 61, 1, 55-62, (2018)

8. Christensen Clayton M. The Innovator's Dilemma When New Technologies Cause Great Finns to Fail, Boston,MA:Harvard Business School Press,(1997)

9. Chou J R. A Study on the Conceptual Design Method Based on Extension Method, Journal of Computational and Theoretical Nanoscience 9, 1, 861-866, (2012)

10. Ilevbare I M, Probert D, Phaal R. A review of TRIZ, and its benefits and challenges in practice, Technovation 33, 30-37,(2013) 